\title{
Quality of Services with Respect to their Unique Characteristics - The Field of Education
}

\author{
By Peter Madzik ${ }^{*}$ \\ Miroslav Hrnciar
}

Services have various unique characteristics compared to other types of products. Any approach to quality control of services must respect and be based on these unique characteristics. In addition to the often mentioned four major characteristics of services intangibility, variability, inseparability and perishability, some authors also mention other unique characteristics - "customer as input and co-producer of service" among them. According to available sources, the relation between four major characteristics of services and problems of quality was proved, but research concerned with the "customer as input and co-producer of service" characteristic is rare. However, in the case of university education, the characteristic "customer as input and co-producer of service" is of key importance. This article uses statistical analysis of survey results in order to prove the validity and importance of this unique characteristic for the field of university education. Research results are based on the evaluation of an enquiry action (questionnaire) in which a total of 243 responses from the graduates of the Faculty of Management Science and Informatics of the University of Žilina in Žilina were processed.

\section{Introduction}

The orientation of advanced market economies towards education and its quality has been considerable in recent years. It is obvious not only from looking at the Bologna declaration and accompanying documents, but also at the amount of finances that is being allocated to this field (ENQA, Standards and Guidelines for Quality Assurance in the European Higher Education Area, 2005). In order for these resources to be spent effectively, it is necessary to know (and measure) those factors that have the biggest influence on the resulting quality of a school's product - education. From the viewpoint of economic classification of activities, the process of education is counted among services.

The nature of services is specific compared to other types of products they are intangible, variable, inseparable and perishable. The ability to manage

*PhD Student, University of Zilina, Slovakia.

${ }^{\dagger}$ Associated Professor, University of Zilina, Slovakia. 
these particular unique characteristics (in some sources referred to as "particularity" of a service) has a provable impact on the resulting quality of a service (Uram, 2012). Knowledge of factors that together form a particular unique characteristic should be the first step to quality control also in the field of education.

"A quality is degree to which a set of inherent characteristics fulfils requirements" (ISO, 2008). This definition is broad and at the same time accurate enough to be applied to many fields - including education. Inherent characteristics are all features and attributes of education, e.g., structure of a study programme, technical equipment, attitude of teaching staff, etc... These characteristics are subject to demands from various interested parties (students, employers, countries, regions, university executives...). Customer satisfaction is one of the most important indicators of quality. In the case of universities, students or graduates and employers are the most important customers (Sandmaung, 2013). Surveys of students' or graduates' satisfaction are some of the most important indicators of a university's efficiency. It is therefore necessary to pay attention also to the factors that influence the level of satisfaction (Konx, 2012).

Majority of professional sources call factors influencing the quality of service and satisfaction with the same the attributes of quality (Lovelock, 2001) (Fitzsimmons, 2006) (Gronroos, 2007). The attribute is part or component of a product (product or service), to which a special attention should be paid in order to achieve conformity with requirements of the interested party. Several approaches are in the measurement of quality of educational services usually based on the evaluation of supporting processes (ISO, 2003) and educational sources (Eurashe, 2012). Our research is aimed at the examination of the research gap arising from ambiguously defined particularity of services in the area of education: student (customer) as the co-producer of service and determinant of its quality. We are attempting to determine through empiric research whether there exists a dependence between the degree of maturity of students (measured through the complex development of student's personality by the Faculty) and general quality of the provided service (measured through the satisfaction with education).

\section{Problem Definition}

Characteristics of services are defined in various ways by various authors. According to Lovelock, the four most often mentioned characteristics of services (intangibility, variability, perishability, inseparability) are not always applicable to all services (Lovelock, 2004). Many other authors mention further characteristics of services.

Uram's research has proven that the four most often mentioned characteristics of services (intangibility, variability, inseparability and perishability) have a provable effect on the types of problems faced in services (Uram, 2012). However, in the field of education, the fifth characteristic is also 
crucial - customer is an input and a co-producer of a service. It is therefore necessary to verify whether the attitude of a customer (in our case a student) has a provable effect on the overall quality of the provided service (in our case education). This research makes it possible to confirm or refute the aforementioned claims concerning the validity of this characteristic of services.

Table 1. Major Characteristics of Services

\begin{tabular}{|c|c|c|c|c|c|c|c|c|c|c|c|c|c|}
\hline & & 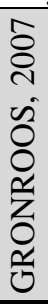 & 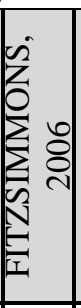 & 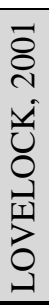 & 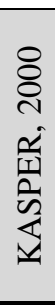 & $\begin{array}{l}\stackrel{2}{\sigma} \\
z \\
\underset{0}{Z}\end{array}$ & 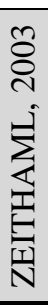 & 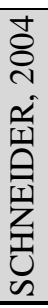 & 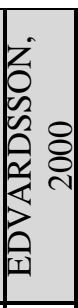 & $\begin{array}{l}8 \\
8 \\
\text { ते } \\
\text { v } \\
\text { II }\end{array}$ & 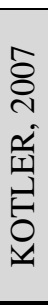 & 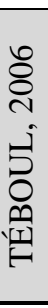 & 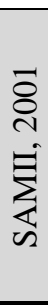 \\
\hline \multirow{4}{*}{$\begin{array}{l}4 \text { major } \\
\text { characte- } \\
\text { ristics } \\
\text { of services }\end{array}$} & Intangibility & & $\mathrm{x}$ & & $\mathrm{x}$ & $\mathrm{x}$ & $\mathrm{x}$ & $\mathrm{x}$ & $\mathrm{X}$ & $\mathrm{x}$ & $\mathrm{x}$ & & $\mathrm{x}$ \\
\hline & Variability & $\mathrm{x}$ & $\mathrm{x}$ & $\mathrm{x}$ & $\mathrm{x}$ & $\mathrm{x}$ & $\mathrm{x}$ & $\mathrm{x}$ & & $\mathrm{x}$ & $\mathrm{x}$ & $\mathrm{x}$ & $\mathrm{x}$ \\
\hline & Inseparability & $\mathrm{X}$ & $\mathrm{x}$ & & $\mathrm{x}$ & $\mathrm{x}$ & $\mathrm{X}$ & $\mathrm{X}$ & $\mathrm{X}$ & $\mathrm{x}$ & $\mathrm{x}$ & $\mathrm{X}$ & $\mathrm{X}$ \\
\hline & $\begin{array}{l}\text { Perishability / } \\
\text { *unstorability }\end{array}$ & & $\mathrm{x}$ & $\mathrm{X}^{*}$ & $\mathrm{x}^{*}$ & $\mathrm{x}$ & $\mathrm{X}$ & & $\mathrm{x}$ & $\mathrm{X}$ & $\mathrm{x}$ & & $\mathrm{X}$ \\
\hline \multicolumn{2}{|c|}{$\begin{array}{l}\text { customer is input and } \\
\text { co-producer of service }\end{array}$} & $\mathrm{x}$ & $\mathrm{x}$ & $\mathrm{x}$ & & & & & $\mathrm{x}$ & & & & \\
\hline \multicolumn{2}{|c|}{$\begin{array}{l}\text { service is a process } \\
\text { (set of activities) }\end{array}$} & $\mathrm{X}$ & & $\mathrm{x}$ & & & & & & & & $\mathrm{x}$ & \\
\hline
\end{tabular}

Source: (URAM, 2012)

The presented table represents a cross-section of the main particularities of services from the point of view of the most significant authors. As implied by the table, authors partially neglect an important feature of the service, present especially in education, namely the fact that "the customer is input and coproducer of service". The presented research is aimed at examination of this feature. The Accreditation Commission of the Slovak Republic established on the grounds of findings an unacceptable unemployment rate of graduates from Slovak universities, what led to an adjustment of the set of criteria for evaluation of quality of universities (Msvvas, 2013). The unemployment rate of graduates was included in the set of criteria.

However, various sociological research indicates changes in behaviour, habits and life-style of today's generation of university students (Zvalova, Srnankova, \& Hrusovska, 2008). All the beforementioned pieces of information thus seem to lead to the following question: "Is quality of education influenced by students themselves?" Many authors interested in theory of services claim that ,customer (in this case student) is an input to the process of providing a service (in this case education)" (Lovelock, 2001) (Fitzsimmons, 2006) (Gronroos, 2007). The result of a process of education is an output - i.e., education. However, if the inputs are of a „low quality“, then this fact should also bear on the quality of outputs. Further research of this factor is based on the following problem definition: 
"Is it possible to prove a relation between the maturity of a student's personality and the quality of education?"

As a means of solving this problem, a survey was conducted among graduate students of the Faculty of Management Science and Informatics of the University of Zilina. The existing database of graduate students of all study programmes at the Faculty from the last 5 years was used.

\section{Building Hypothesis}

In order to solve the defined problem, it was necessary to divide it into its components. The first component is the maturity of a student's personality. We can measure how mature a student was at the beginning of her study (how well defined were her life goals and desired achievements) and how her personality evolved during the study under the influence of the faculty. The second component is the quality of education - i.e., the extent to which a student considers the acquired education a quality one. Since the solution of the problem was based on a survey, the hypothesis was built according to recommendations for hypothesis-formulation in sociological-psychological surveys (Gavora, Koldeova, \& Dvorska, 2010). According to several sources, a hypothesis should consist of two variables (attributes), where one of them must be bivalent (A1) and the other must show various values (A2) (Good, 2005) (Sa, 2007). Based on this, the following hypothesis was formulated:

"Students who claimed an above-average contribution from the faculty (A1) were more satisfied with the quality of education (A2)."

\section{Methodology}

\section{Decomposition of Attributes}

Two attributes are present in the aforementioned hypothesis. Values necessary for statistical examination were assigned to these attributes in the following manner.

\section{Attribute "A1" - Coefficient of Faculty's Contribution}

In order to assess the contribution of the faculty to personality development of students, it is necessary to know their "maturity" not only at the end of their study, but also at the beginning and during the study. To decompose this attribute, the scenario method in combination with a tree diagram and a flowchart diagram were used (Grigoroudis \& Siskos, 2010). "Faculty's contribution coefficient" was introduced at the Faculty of Management Science and Informatics. This coefficient consists of calculation of values obtained from the following questions: 
- Did the student have a clear idea about her profession when she began her study?

- If yes, was she studying a programme that corresponded with that idea?

- If no, did the faculty help her make clear that idea during her study?

- If no, was she able to make the idea clear after her study?

- To what extent did she consider her study a positive contribution to her personality development?

Since the questions are conditional, the user interface of the electronic questionnaire was adjusted accordingly. The contribution of the faculty to personallity development of a particular student was calculated as the product of answers to the above questions (by multiplying $\mathrm{X} 1 * \mathrm{X} 2 * \mathrm{X} 3 * \mathrm{X} 4$ ). Coefficients of particular answers were set using a structured interview with the teaching staff - their values are present in the highlighted area of picture 1.

If a graduate had a partial idea of her profession before the beginning of her study, then value A (i.e., X1) is 0,83 . If the programme she studied corresponded to her idea, then value A1 (i.e., X2) is 1 . If she considered the extent of the contribution of the faculty as $67 \%$ (i.e., X4), then the product gives as a value of 0,553 , or a $55,3 \%$ contribution of the faculty. In this way, contribution of the faculty was calculated for each graduate. Thereafter, the average value was calculated from all those values and graduates were divided into two groups:

a) Graduates who considered the contribution of the faculty to their personality development below the average

b) Graduates who considered the contribution of the faculty to their personality development above average

Using this classification, the aforementioned condition requiring one bivalent variable is fulfiled. 
Figure 1. Calculation of the Coefficient of Contribution to Personality Development

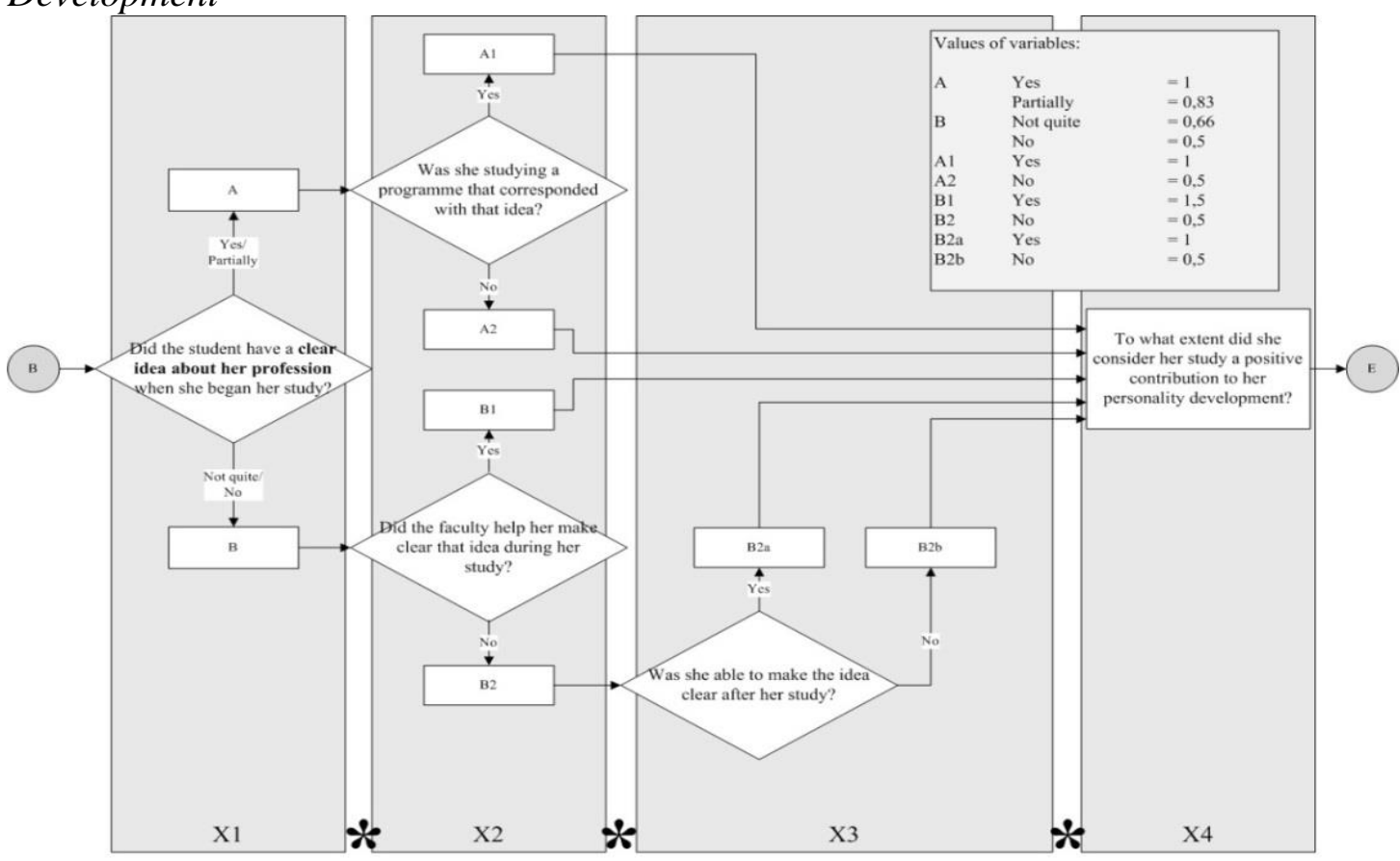

Source: Own processing

\section{Attribute "A2" - Satisfaction with Education}

Attribute of satisfaction with education "A2" and its division into questions are based on methodology for customer satisfaction measuring - CSI (Customer satisfaction index) (Grigoroudis \& Siskos, 2010). Here it is necessary to know the essential factors that influence satisfaction of customers (in this case students) and then to formulate questions that investigate not only the satisfaction with these factors, but also their importance. This attribute consisted of six factors and respondents had to evaluate them according to their perceived importance and satisfaction:

- Structure of subjects of study programme

- Expertness of teaching staff

- Pedagogic abilities of teaching staff

- Study resources, technology, equipment

- Faculty atmosphere

- Support for student creativity

The acquired data enables us to calculate the index of satisfaction according to the formula (Sa, 2007) (Nenadal, 2004):

$$
C S I=\sum\left(\frac{w_{i}}{\sum w_{i}} * s_{i}\right),
$$

where
W - weight (importance) of part of quality

$\mathrm{s}$ - satisfaction with part of quality

$\mathrm{i}$ - number of part of quality 
Seven-level Likert scale with verbal interpretation was used for input of values for importance and satisfaction. Thereafter, the values were converted into per cent according to the following relation (Grauzel \& Hrnciar, 2003):

$V_{\%}=\left(V_{N}-1\right) * \frac{100}{D-1}$

where
$\mathrm{V}_{\mathrm{N}}$ is measured value on the scale,

$\mathrm{D}$ is the range of the scale (7 values)

\section{Data Collection}

The process of data collection took the form of an electronic questionnaire presented through web interface to subjects from the database of graduates from Faculty of Management Science and Informatics (FMSI). Invitations to the survey were sent from an official e-mail account of one of the authors.

\section{Data Processing}

Collected data was stored on a faculty server without third-party access, which was clearly stated when approaching graduates (we surmise this statement led to the relatively high return rate). The database of the results was exported into SPSS Statistics environment where all necessary statistical examination took place in order to test the hypothesis. First of all, we examined the distribution of the data to see how well it corresponded with the Gaussian (normal) distribution. After that, we carried out an F-test to compare the difference in variance of two sets (the whole set was divided into two parts according to attribute A1), and then a relevant type of Student's t-test was used to test the hypothesis.

\section{Results}

During the survey, 454 FMSI graduates were approached through e-mail and 375 of them replied. The number of correctly filled out questionnaires was 243. Discarded questionnaires were either not $100 \%$ filled in, or the time spent to fill in a particular questionnaire (mostly several tens of seconds) was too short to prove that the graduate paid enough attention to it. The average value for the coefficient of faculty contribution reached $66,8 \%$. The overall index of satisfaction with education reached $66,7 \%$.

\section{Test for Normality of Data}

In order to set the right statistical method for testing the two formulated hypotheses, it was necessary to verify the distribution of the sample data set. Judging from the data itself, it seemed that Gaussian distribution could be expected. In order to verify whether the data really shows Gaussian distribution two tests were used - the Kolmogorov-Smirnov and the Shapiro-Wilk test. Of course, only attribute A2 could have been tested, since only this attribute was of the "numeric" type. Attribute A1 was changed into "string" in the following manner: a) above-average contribution of the faculty to personality 
development of the students; b) below-average contribution of the faculty to personality development of the students. The results of statistical examination can be seen in the folowing table and picture.

Table 2. Results of Test for Normality

\begin{tabular}{|c|c|l|}
\hline \multicolumn{2}{|c|}{} & A2 - CSI \\
\hline \multirow{4}{*}{$\begin{array}{c}\text { Kolmogorov- } \\
\text { Smirnov }\end{array}$} & Critical value & 0,025 \\
\cline { 2 - 3 } & Calculated value & 0,075 \\
\cline { 2 - 3 } & Result & $\begin{array}{l}0,025<0,075= \\
\text { Data shows } \\
\text { NORMAL } \\
\text { distritution }\end{array}$ \\
\hline \multirow{5}{*}{ Shapiro-Wilk } & Critical value & 0,023 \\
\cline { 2 - 3 } & Calculated value & 0,981 \\
\cline { 2 - 3 } & Result & $\begin{array}{l}0,023<0,981= \\
\text { Data shows } \\
\text { NORMAL } \\
\text { distritution }\end{array}$ \\
\hline
\end{tabular}

Source: Own processing

Figure 2. Results of Data Normality Tests
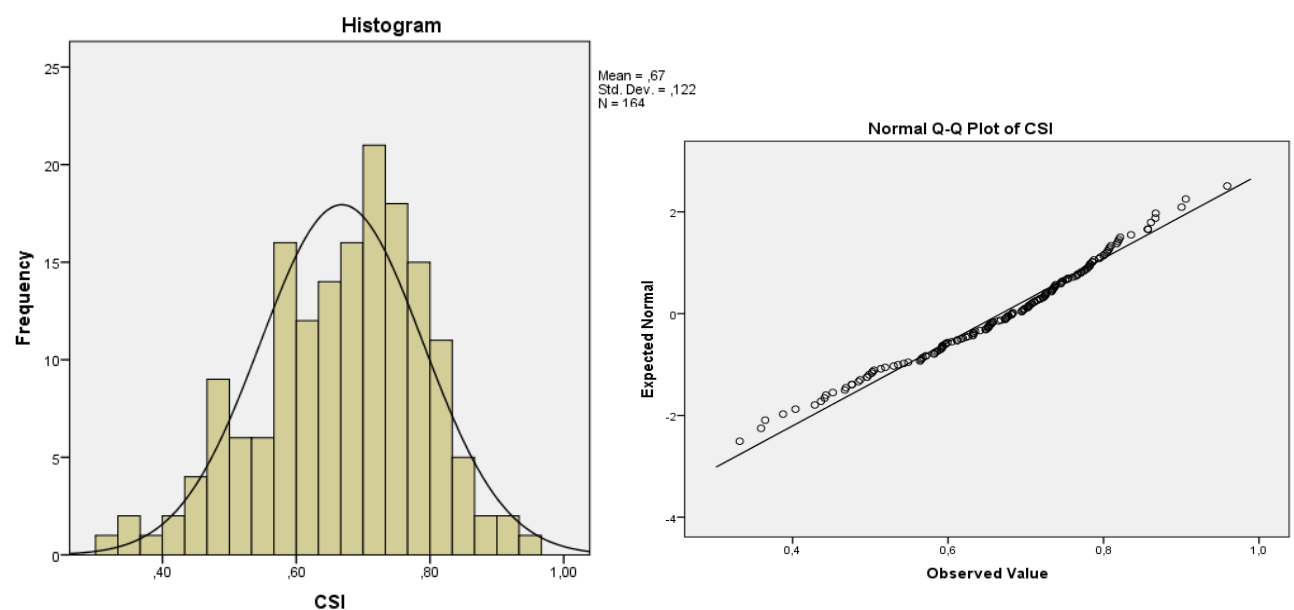

Source: Own processing

The attribute shows normal distribution. This fact leads next statistical examination into the area of parametric methods. The most ofen used method is Student's t-test which may be of two types: Two-Sample Assuming Equal Variances and Two-Sample Assuming unequal Variances (Sa, 2007). In order to choose one of them, it is necessary to perform a variance analysis.

\section{Analysis of Variance (ANOVA)}

In case of attribute A2, the sample dataset was divided into two independent sets. "Contribution of the faculty to personality development of the student" (A1) was used as the class mark. This attribute was chosen with regard to the research problem and to its presnece in the hypothesis. Thereafter, attribute A2 was tested using the Two-Sample for Variances F-Test (Sa, 2007). 
The results can be seen in the following table:

Table 3. Results of ANOVA

\begin{tabular}{|c|c|c|}
\hline \multicolumn{1}{|c|}{} & A2 - CSI \\
\hline \multirow{4}{*}{ F-test } & Critical value & 1,476 \\
\cline { 2 - 3 } & Calculated value & 1,441 \\
\cline { 2 - 3 } & Results & Variance of the two datasets is statistically \\
& EQUAL \\
\cline { 2 - 3 } & $\begin{array}{c}\text { Further testing } \\
\text { requires: }\end{array}$ & t-Test: Two-Sample Assuming Equal Variances \\
\hline
\end{tabular}

Source: Own processing

Hypothesis Test

Before the test we should examine whether the formulated hypotheses are valid on the basic level. The hypothesis was:

"Students who indicated an above the average contribution of the faculty (A1) were more satisfied with quality of education (A2).“

As can be seen from the following table, our results prove the hypothesis. Student's t-test (two-sample assuming equal variances) was used to examine whether the differences are statistically significant. The results are as follows:

Table 4. Results of Hypothesis Test

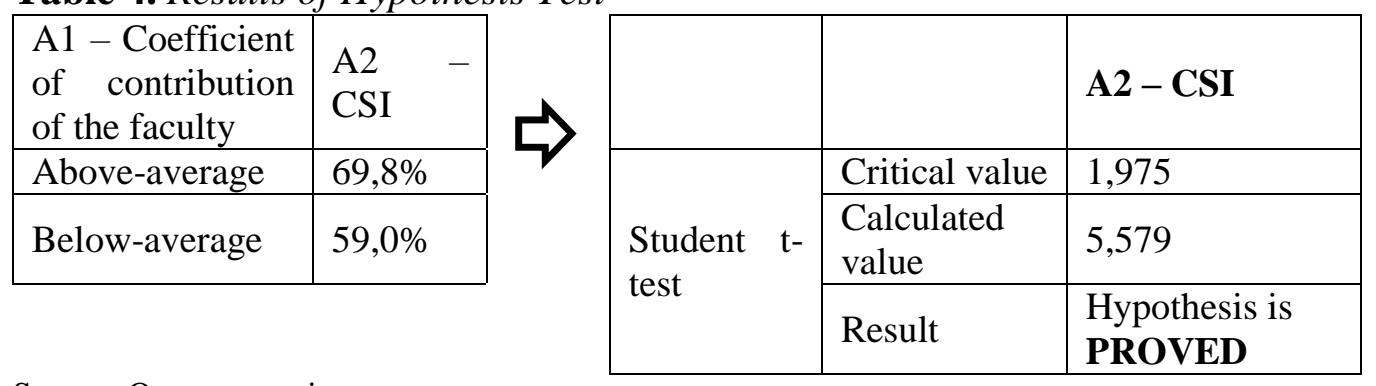

Source: Own processing

Statistical examination proved that students who perceived the contribution of the faculty to their personality development as above-average (compared to all students participating in the survey) were in general more satisfied with the education. Thus the authors' assumption that the influence of a university/faculty on a student's personality presents an important factor in education was proved.

\section{Discussion}

The influence of a university/faculty on how students generally perceive the quality of offered education is essential, as was shown by proving the formulated hypothesis. A university should not only pay attention to the structure of study programmes, the teaching staff and technical equipment, but should also form its students' personalities. That can be achieved by way of a 
higher participation of students in scientific and research activities of the school or by providing them with more opportunities for conducting research abroad.

Unique characteristics of services play an important part in quality control. If processes in an organisation providing services (in our case a university) are adjusted in a manner that respects these characteristics, then severe failures of those services can be avoided. The failures are disproportions between the expected and perceived quality of a service in its respective stages, as defined by GAP analysis (Parasuraman, 1988). This article presents an approach to the quantification of the characteristic "customer as input and co-producer of service" using the coefficient of the faculty's contribution which was introduced at the Faculty of Management Science and Informatics. Management of unique characteristics of services still has a lot to offer and the authors would like to believe that this article will contribute to a broader professional discussion in this field.

\section{Conclusion}

Growing pressure on universities from governing institutions is often the result of international agreements to carry out international strategies. Universities have gradually started to recognize the potential of quality control tools hitherto used exclusively in the business environment. Several approaches were adapted by educational institutions (for instance, ISO 9001 was the basis for IWA2), but there still exists hidden potential of combining the characteristics of education as a service with approaches of quality control.

Research results confirmed the importance of the perception of a student as a co-producer of service (Lovelock, 2004, Gronroos, 2007, Fitzsimmons, 2006). Examination of hypotheses showed that the development of student's personality by the university is directly proportional to the perceived quality of provided education.

If a university spends more of its resources on this area, it can have a provable effect on students' satisfaction with their study. With respect to the importance of the part students (future graduates) play in the system of education, this effort is not purposeless and can have a profound effect on improving the quality of study and on creating a relationship with the customers of a university - its students and graduates.

That has indirectly confirmed results of previous studies which pointed to the role of the student as a key interested party (as a customer) in the process of evaluation of the general quality of education (Clayson, 2005) (Eagle, 2007). The sector of education is, similarly as other services, typical by four general particularities, whereas the fifth particularity - that "the customer is input and co-producer of service" is non-negligible. Used statistic examination confirmed that this particularity is substantiated in the educational environment, what contributed to filling the existing research gap which was identified in previous researches dealing with the issue of educational quality (Galloway, 1998). 


\section{Acknowledgment}

This article was created within the research project VEGA 0888/11 Knowledge management - Models and Applications.

\section{References}

ISO. (2008). ISO 9001:2008 Quality management systems - Requirements. Brusel: CEN.

Clayson, D. E. (2005). Marketing models in education: students as customers, products, or partners. Marketing Education Rview, 15(1), 1-10.

Eagle, L. B. (2007). Are Students Customers? TQM and marketing perspectives. Quality Assurance in Education, 15(1), 44-60.

ENQA. (2005). Standards and Guidelines for Quality Assurance in the European Higher Education Area. Helsinki: ENQA.

Eurashe. (2012). MAP-ESG - Mapping the Implementation and Application of the European Standards and Guidelines for Quality Assurance in the EHEA. Cit. 5. January 2014. Dostupné na Internete: http://www.eurashe.eu/projects/map-esg/

Fitzsimmons, J. F. (2006). Service Mangement. New York: McGraw-Hill.

Galloway, R. L. (1998). Determinants of quality perception in educational administration: Potential conflict between the requirements of internal and external customers. Educational Management Administration and Leadership, 26(1), 35-48.

Gavora, P., Koldeova, L., \& Dvorska, D. (2010). Elektronická učebnica pedagogického výskumu. Bratislava: Univerzita Komenského.

Good, P. I. (2005). Permutation, Parametric, and Bootstrap Tests of Hypotheses. New York: Springer.

Grauzel, J., \& Hrnciar, M. (2003). Kvalita a jej miesto v organizácii. Žilina: EDIS.

Grigoroudis, E., \& Siskos, Y. (2010). Customer Satisfaction Evaluation. New York: Springer.

Gronroos, C. (2007). Service management and marketing.Customer management in service competetion. Chichester: John Wiley \& Sons Ltd.

ISO. (2003). IWA2 Guidelines for the application of ISO 9001:2000 in education. Acapulco: CEN.

Konx, S. P. (2012). Customer relationship management. Oxford: ButterworthHeinemann.

Lovelock, C. G. (2004). Whither Services Marketing?: In Search of a New Paradigm and Fresh Perspectives. Journal of Service Research(7).

Lovelock, C. H. (2001). Services marketing. New York: Prentice Hall.

Msvvas, a. (5. April 2013). Kritériá akreditácia študijných programov vysokoškolského vzdelávania. Cit. 9. January 2014. Dostupné na Internete: http://www.minedu.sk/data/files/2545.pdf

Nenadal, J. (2004). Měrení v systémech managementu jakosti. Praha: Computer Press.

Parasuraman, A. Z. (1988). SERVQUAL:A Multiple-Item Scale for Measuring Consumer Perceptions of Service Quality. Journal of Retailing, 64(1).

Sa, J. P. (2007). Applied Statistics Using SPSS, STATISTICA, MATLAB and R. Berlin: Springer Berlin Heidelberg. 
Sandmaung, M. K. (2013). Quality expectations in Thai higher education institutions: multiple stakeholder perspective. 21(3).

Uram, M. (2012). Zvyšovanie kvality služieb prostredníctvom riadenia špecifických vlastností služieb - dizertačná práca. Žilina: Žilinská univerzita.

Zvalova, M., Srnankova, L., \& Hrusovska, J. (2008). Uplatnenie absolventov vysokých škôl v praxi. Bratislava: ÚIPŠ. 